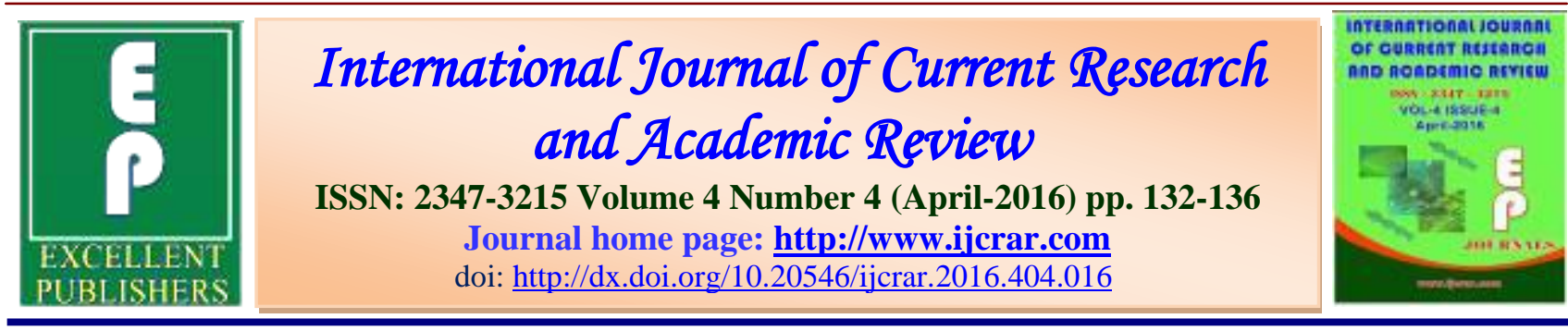

\title{
A Pilot Study of Rural Entrepreneurship Development through Cultivation and Processing of Oyster Mushroom (Pleurotus sajorcaju)
}

\section{Shweta Yadav*}

Department of Zoology, Dr H S Gour Vishwavidalaya (A Central University), Sagar-470003, MP, India

*Corresponding author

\begin{tabular}{|l|l|}
\hline \multirow{2}{*}{$\begin{array}{l}\text { KEYWORDS } \\
\text { Development, }\end{array}$} & A B S T R A C T \\
\cline { 2 - 2 } $\begin{array}{l}\text { Cultivation and } \\
\text { Mushrosing of Oyster }\end{array}$ & $\begin{array}{l}\text { Study carried out during 2008-2011 with establishment of centralized } \\
\text { training, demonstrations, spawns production cum processing unit and six } \\
\text { mushroom cultivation units in the courtyard of groups of farmers located in } \\
\text { village of four blocks at Aligarh, Western UP, India. Initially awareness was } \\
\text { created in about } 300 \text { rural populations regarding benefit and consumption of } \\
\text { mushroom through 50 training programme. Initially all material and technical } \\
\text { support were provided to beneficiaries for commercial production of } \\
\text { mushroom. Author was focused to find out good potential of marketing for } \\
\text { their produce and support with establishment of small groups for marketing } \\
\text { their produce in each block during the study period. }\end{array}$ \\
\hline
\end{tabular}

\section{Introduction}

Mushrooms were included in diet by Greeks and Roman since ancient time. Mushroom has been mentioned in Ramayana as Kukarmukta. Romans regarded them as food of God while Chinese termed them as elixir of life. It was first cultivated in Germany as a subsistence measure during World War I and is now grown commercially around the world for food. In India commercial mushroom cultivation was started in 1971 when its annual production was only 100 tons which has now reached to more than 40,000 tons. It is low calorie diet having high amount of protein, vitamins and minerals.
Oyster mushroom (Pleurotus sp.) is most common among all commercially cultivated mushrooms in India. It has oyster like shape because of which it is popularly known as oyster mushroom. This mushroom genus has about 38 well recognized species out of which 25 species have been reported from India and of which 12 species are cultivated in different parts of our country (Anonymous, 2002). Commonly cultivated species includes Pleurotus sajor-caju, P.ostreatus, P.covus, P.florida, P.platypus and P.sapidus. Naturally it and grows in the temperate and tropical forests on dead, 
decaying wooden logs and on decaying organic matter. Mushroom cultivation is not only of economic importance but also has important role to play in integrated rural development programme by increasing income and self-employment opportunities among the rural areas.

\section{Materials and Methods}

Centralized spawns production cum processing unit and six mushroom cultivation units in the courtyard of groups of farmers located in village of four blocks at Aligarh, Western UP, India was established to generate self employment opportunities in study area.

\section{Results and Discussions}

During the period reported the following activities have been done under the project programme.

(a) Training programme on mushroom cultivation: In order to create awareness and provide technical know-how about cultivation and production of oyster mushroom, twenty training programmes were organized during during 20082011(Fig 2 \& 4). During training a total of 200 farmers were given theoretical lessons followed by practical demonstration and details were explained. Always a separate question answer session were kept in schedule to help farmers and solve their petty doubts. Efforts were made to provide them information on appropriate level of moisture, diseases, packaging etc. that may adversely affect the production and sale of mushroom.

(b) Production of Spawn $550 \mathrm{~kg}$ mushroom spawn (Oyster mushroom) of Pleurotus sajorcaju and $300 \mathrm{~kg}$ spawn of $P$. astreatus have been produced at the laboratory set-up under the programme for providing to interested beneficiaries for mass scale production of mushroom.

(c) Establishment of Mushroom Units at Farmers village: Following training at 6 mushroom production units has been set-up in Aligarh, Hathras and Etah districts of western U.P. at farmers land. $500 \mathrm{~kg}$ spawn 50 litre formalin and $5 \mathrm{~kg}$ fungicide were provided to 42 farmers to set-up their own production units in villages and 30 Mushroom production units have been setup under the guidance and day-to-day technical supervision of project staff. The six farmers established mushroom production unit at large scale (Fig 3).

(d) Participation in Exhibitions

To create awareness for cultivation, production and processing of oyster mushroom there were continuous demonstrations of technology involved through the project participation in 5 exhibitions during the period reported(Fig $3)$.

(e) Oyster Mushroom-Economics

Economics of oyster mushroom cultivation for the study area was calculated by using $200 \mathrm{~kg}$ Paddy Straw/batch of $10 \mathrm{~kg}$ Mushroom/batch.

\section{Conclusions}

It is hoped the mushroom cultivation and production units set up at farmers fields under the project programme may prove to be a boon in supplementing their income and improve economy in rural sector. However, there are certain issues identified during the study mainly, i) poor resource base of the farmers to take it up at commercial scale; ii) lack of specific project 
or programme to promote the enterprise; iii) high temperature or lack of cold chain; v) yield fluctuations due to climate changes; v) substandard marketing facility and absence of fixed price for mushroom.

A. Details of expenditure

1. Capital cost
(a) Thatched shed with wooden platform
Rs. $\quad 1,2500.00$ ( $250 \mathrm{sq} . \mathrm{ft}$.)
(b) Vessels, heating equipment and Rocker sprayer-set
Rs. $\quad 4000.00$
2. Recurring cost (for first batch capitalized)
$\begin{array}{lll}\text { (a) Polythene bags (200 nos) } & \text { Rs. } 600.00\end{array}$
$\begin{array}{lll}\text { (b) Paddy straw }(200 \mathrm{~kg}) & \text { Rs. } & 800.00\end{array}$
$\begin{array}{lll}\text { (c) Spawn } 50 \text { bottles } & \text { Rs. } 1000.00\end{array}$
$\begin{array}{lll}\text { (d) Labour charges } & \text { Rs. } 600.00\end{array}$
(e) Fuel cost - Lump sum Rs. 3700.00
Rs. $\quad 20,200$

B. Assumptions
1. Recurring cost/year
2. Yield assumption
3. Sale price (Rs, per $\mathrm{kg}$ )
Rs, $\quad 14,800.00$ $400 \mathrm{~kg}$ ( 4 batch per year)
Rs. $\quad 60.00$

C. Financial Indicators

\begin{tabular}{lrr} 
Item & $\begin{array}{r}\text { Ist year } \\
\text { Expenditure }\end{array}$ & Rs. \\
14800.00 \\
IncomeRs. & & 24000.00 \\
\hline Net income: $(24,000.00-14,800.00)$ & Rs. & 9200.00 \\
\hline
\end{tabular}

Figure.1 An Inside View of Mushroom House Depicting Mushroom Bags: Note Production of Mushroom During 2009-2010

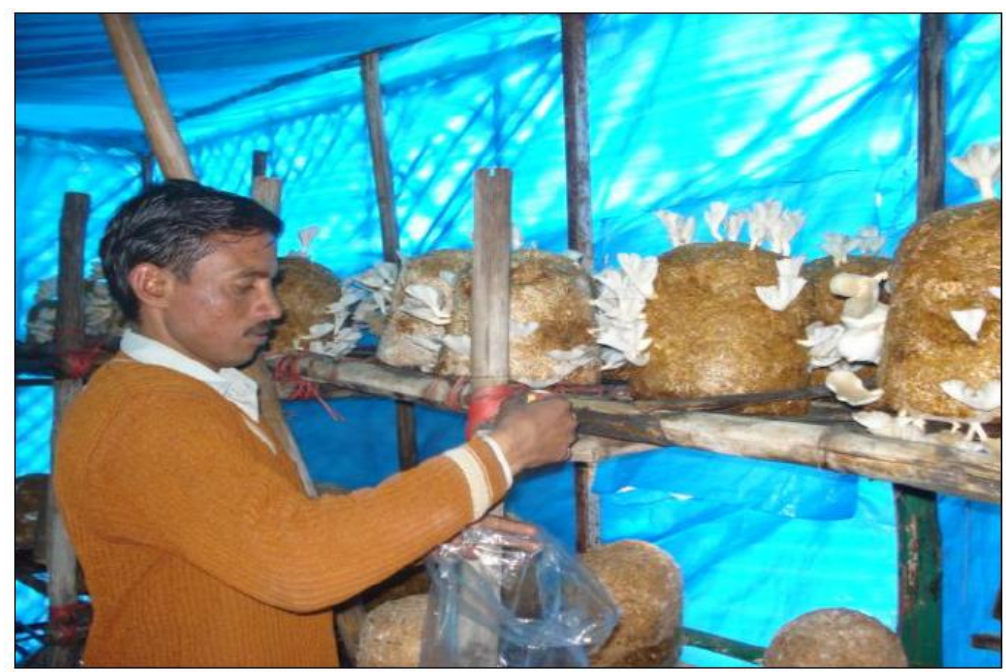


Figure.2 A View of Training Program on Cultivation and Processing of Mushroom Organized under the Project

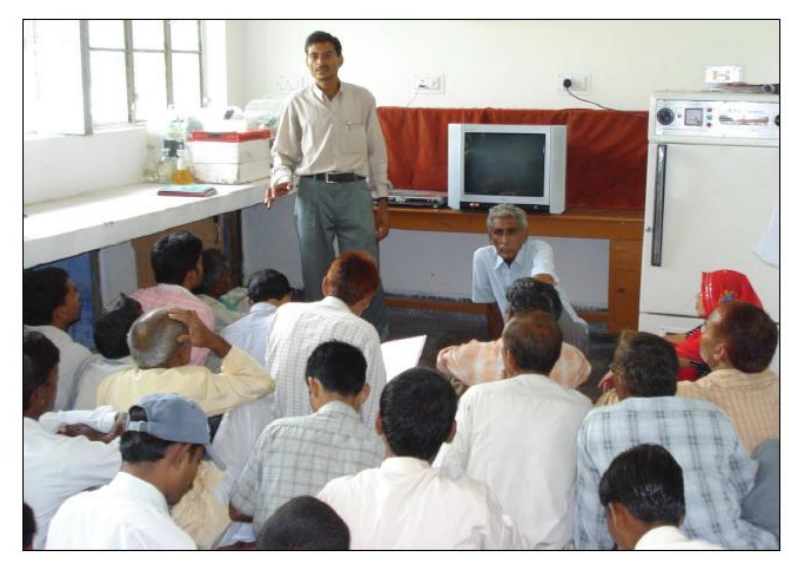

Figure.3 A View of Project Participation in Aligarh Agricultural and Industrial Exhibition, 2010 To Create Awareness about Mushroom Cultivation.

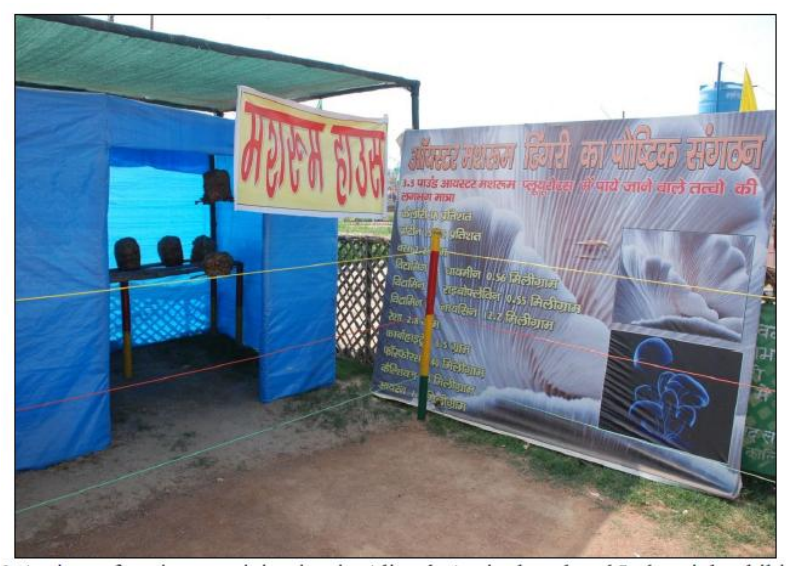

Figure.4 A Mushroom Production Unit Set-up during 2009-2010 at Village Chaudhana, Block Khair, distt. Aligarh Set-up under the Guidance of the Project.

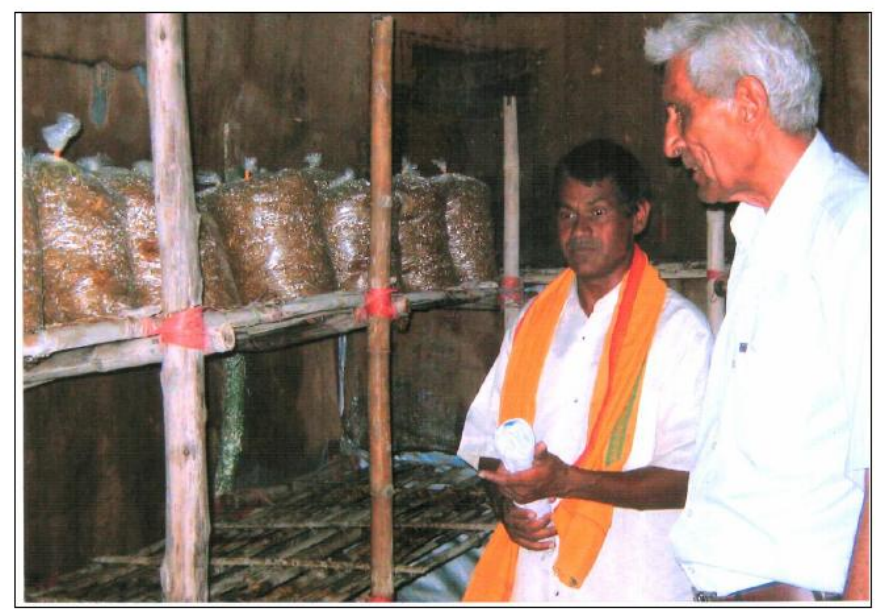




\section{Acknowledgement:}

We acknowledge the financial support of the Department of Science and Technology, Govt. of India, New Delhi, to carry out this study.

\section{References}

Anonymous, 2002. Mushroom cultivation: An emerging rural industry. Indian
Agriculture Research Institute, New Delhi-110012, India.

Shweta Yadav, 2011. Report on Rural Entrepreneurship development through training and demonstration on cultivation and processing of mushroom Project No. : SSD/SCSP 1046/ 006, Department of Science and Technology, Govt. of India, New Delhi.

\section{How to cite this article:}

Shweta Yadav. 2016. A Pilot Study of Rural Entrepreneurship Development through Cultivation and Processing of Oyster Mushroom (Pleurotus sajorcaju). Int.J.Curr.Res.Aca.Rev.2016; 4(4): 132-136.

doi: $\underline{\text { http://dx.doi.org/10.20546/ijcrar.2016.404.016 }}$ 